原一著

$$
\begin{aligned}
& \text { 一側性メニエール病の両側移行例の検討 } \\
& \text { : ゲンタマイシン鼓室内注入療法の適応検討の観点から } \\
& \text { 松崎 真樹・室伏 利久 }
\end{aligned}
$$

\title{
A Clinical Study of the Progression to Bilateral Meniere's Disease from Unilateral Meniere's Disease: From the Viewpoint of the Indication of Intratympanic Gentamicin Injection Therapy
}

\author{
Masaki Matsuzaki, Toshihisa Murofushi \\ Department of Otolaryngology, Tokyo Postal Services Agency Hospital
}

Intratympanic gentamicin injection has been used as a treatment of intractable Meniere's disease (MD). Although this therapy is supposed to be applied to unilateral $\mathrm{MD}$, it should be noted that unilateral MD progresses to bilateral MD at a rate of 10$40 \%$. Involvement of the contralateral ear after gentamicin injection could cause the serious problem of bilateral inner ear disfunction. To predict the future involvement of the contralateral ear, we reported a prospective study of patients that were diagnosed with unilateral MD at the first examination. Among 71 patients with unilateral MD, 9 (12.6\%) showed fluctuating hearing loss in the contralateral ear. The average interval of the contralateral involvement after the unilateral involvement was 8.7 years. Although the prediction of the contralateral involvement was difficult from the results of the pure tone audiometry, caloric test and vestibular evoked myogenic potential, these bilateral cases tended to be seen more in females and in patients of older ages at the onset of the disease. The results of this study revealed that there is a possibility of contralateral involvement for more than 10 years, and the incidence of bilateral involvement is high in female patients who were over 60 at the onset of the disease.

Key words: Meniere's disease, bilateral, gentamicin

\section{はじめに}

メニエール病（以下，MD）に対するゲンタマ

イシン鼓室内注入療法（以下，ゲンタマイシン療

法）は現在広く行われているが，適応条件として

は一般の薬物療法に抵抗性であること，一側性で あること，良聴耳でないことなどが挙げられるい

ここで問題となるのは一側性 MD として加療

東京聥信病院耳鼻咽喉科
中に両側性に移行した場合で，一側内耳破壊後に 反対側の難聴・前庭機能低下（対側発症）を生し た場合，長期的には両側高度難聴・前庭機能廃絶 をきたす可能性がある。これに対し，対側発症の 危険性をあらかじめ予测できればこらしたリスク を減少させられると考兄られる。

ゲンタマイシン療法施行時の注意点を再確認す ることを目的に，初殓時一側性 MDであった症 例の経過中対側発症をきたした症例について，そ 
の特徵の有無を調べ，文献報告と比較検討した。

\section{対象と方法}

対象は東京大学附属病院耳鼻咽喉科を1994年以 降に初診し，この時点で一側性 MD と診断され た後，最低 1 年以上経過観察ができた 71 症例であ る。診断基準には厚生省研究班のメニエール病診 断基準を採用した6)。平均約 35 力月の経過観察中 反対側に聴力変動が出現した場合を対側発症と定 義した。経過中対側聴力に変動をきたさなかった 一側性症例と以下の項目について比較検討した。

男女比/初診時年齢/発症から初診までの罹病 期間 /カロりックテスト・前庭性頸筋電位 (VEMP) の結果 (施行例のみ)

対側発症例については加えて以下の項目を検討 した。

対側発症までの期間 /初発耳と後発耳（対側 耳）の難聴のタイプ/対側発症時のめまいの有無 なお，経過中ゲンタマイシン療法を施行した症 例は除外した。

\section{結 果}

\section{1) 一側例}

経過中対側発症を認めなかった一側例は全71例

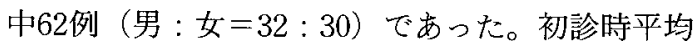
年齢は49.6歳（男 48.4 歳，女50.9歳）であり，発 症から初診までの罹病期間は平均 3.8 年（0年〜 27年）であった（表 1)。

カロリックテストは56例に叔いて以下の通りの データを得られた（図 $1 \mathrm{a}$ )。CP なし(数值不明) 扣よび CP 20\%未満 30例 (54\%)，CP+（数值不 明） 3 例 (5\%)，CP 20\%以上50\%未満 14例（25 $\%), \mathrm{CP} 50 \%$ 以上 9 例 (16\%)。

VEMPについては20例に祘いて以下の通りの
データを得られた（図 1 b)。患側振幅低下は（患 側 $\mathrm{p} 13-\mathrm{n} 23$ の振幅／健側 p13-n23 の振幅）< 0.5 ，患側振幅增大は（健側 $\mathrm{p} 13-\mathrm{n} 23$ の振幅／患 側 $\mathrm{p} 13-\mathrm{n} 23$ の振幅）<0.5と定義した。正常： 5 例 $(25 \%)$ ，患側振幅低下 6 例 $(30 \%)$ ，患側無反 応 4 例 (20\%), 患側振幅増大 1 例 $(5 \%)$, 両側 無反応 4 例 $(20 \%)$ 。

2 ) 対側発症例

経過中反対側に聴力変動を生じた対側発症例は 全71例中 9 例（男:女 $=2: 7$ ）であり，今回の 検討で初診時一側性 MD とされた症例が経過中 に対側発症した割合は $9 / 71=12.6 \%$ となった。 初診時平均年路浪66.0歳であり，発症から初診ま での罹病期間は平均7.1年（ 0 年〜 11年）であっ た(表 1 )。

初発耳発症から対側発症までの期間は平均 8.7 年（ 2 年 14年) で， 5 年以内 2 例 $(22 \%) ， 6$ $\sim 9$ 年 2 例 $(22 \%), 10$ 年以上 5 例 (56\%) であっ た。初発耳 (初診時) と後発耳 (対側発症時) の 難聴のタイプの比較を表 2 に示したが，初発耳の 難聴に様々なタイプが認められるのに対し, 後発 耳では低音障害型の割合が比較的多かった。対側 発症時にめまいを伴ったのは 4 例，伴わなかった のは 5 例で，泀涪同数であった。

カロリックテストは全例に括いて以下の通りの データを得られた（図 $1 \mathrm{a}$ )。初発側 $\mathrm{CP}$ なし（数 值不明）および CP 20\%末満 6 例 $(67 \%), C P$ $20 \%$ 以上 $50 \%$ 未満 2 例 (22\%), CP 50\%以上 1 例 $(11 \%)$ 。

VEMPについては 5 例に括いて以下の通りの データを得られた（図 $1 \mathrm{~b}$ )。正常: 2 例 (40\%), 初発側振幅低下：1例 $(20 \%)$, 初発側無反応 2

表 1 一側例と対側発症例の疫学的比較

\begin{tabular}{|c|c|c|}
\hline & 一側例（N=62） & 対側発症例 (N=9) \\
\hline 男 : 女 & $32: 30$ & $2: 7$ \\
\hline 初診時平均年齢 & 49. 6 墄 & 66.0 藏 \\
\hline 初䛦までの罹病期間 & 3.8 年 & 7.1 年 \\
\hline 初発時から対側耳発症までの期間 & - & 8.7 年 \\
\hline
\end{tabular}


a. カロリックテスト
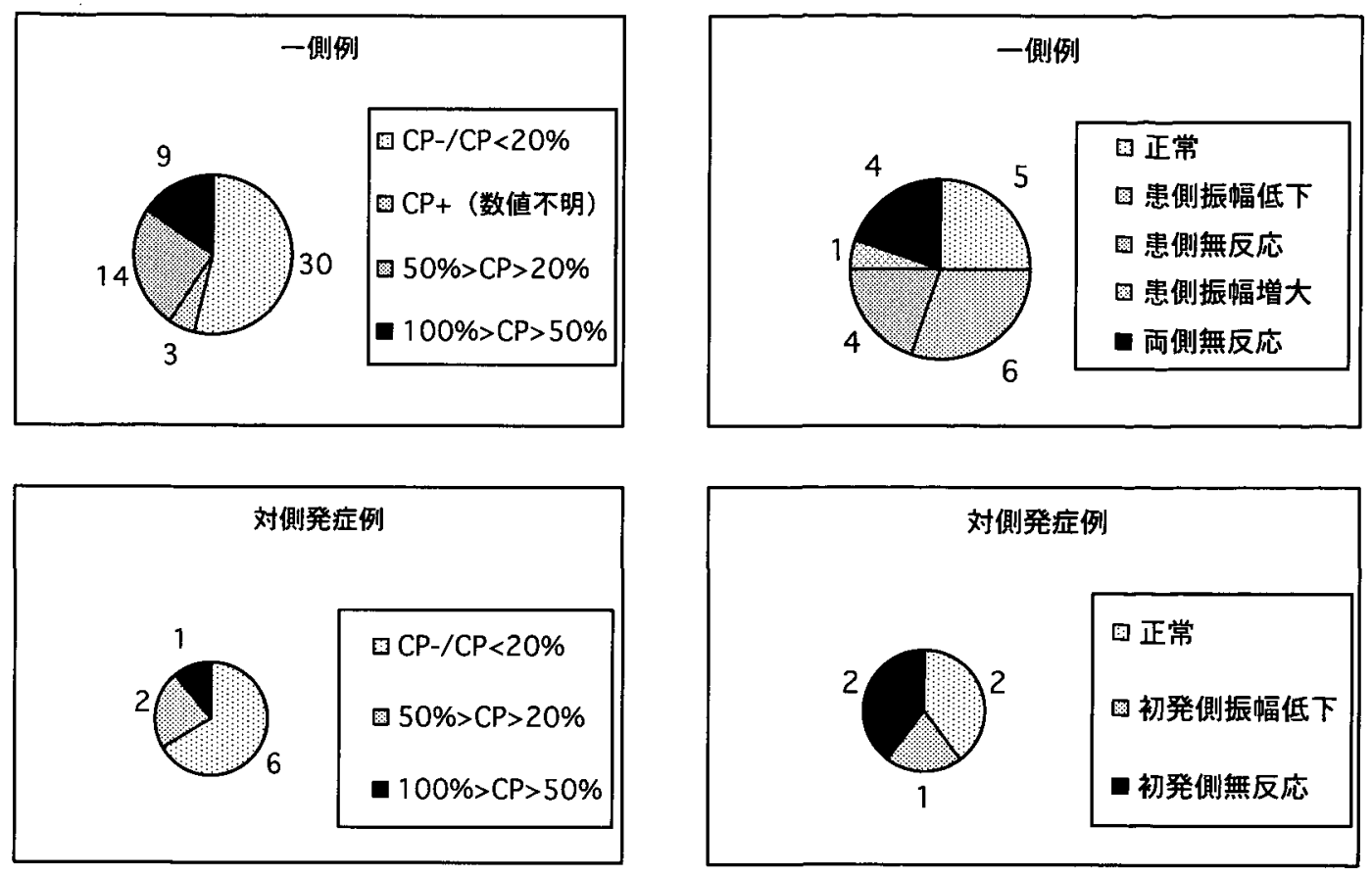

図 1 カロりックテストと前庭性頸筋電位 VEMP の結果

表 2 対側発症例に扣ける初発耳と後発耳の難聴のタイプの比較

\begin{tabular}{|c|c|c|c|c|}
\hline & 初発耳（初診時） & 後発耳（発症時） & 後発耳発症時 & 後発耳聴力 \\
\hline 1 & 低音障害型 & 低音障害型 & めまいなし & 変動あり \\
\hline 2 & 高音急㖏型 & 低音障害型 & あり & あり \\
\hline 3 & 水平型 & 高音急珡型 & あり & あり \\
\hline 4 & Dip 型 & 低音障害型 & なし & あり \\
\hline 5 & 水平+高音急鐆型 & 水平型 & なし & あり \\
\hline 6 & 水平型 & 水平型 & なし & あり \\
\hline 7 & 高音急壁型 & 水平+䯩音急壁型 & なし & あり \\
\hline 8 & 水平型 & 高音漸傾型 & あり & あり \\
\hline 9 & 水平+高音急壁型 & 水平+高音急墜型 & あり & あり \\
\hline
\end{tabular}


例 $(40 \%)$ 。

\section{考察}

一側性 MD の対側発症については過去多くの 報告がある7 12)。平均約10年の経過観察期間での 報告をみると対側発症率は10～40\%とややばらつ きがある。今回初診時一側性 MD が経過観察中 に対側発症した割合は $12.6 \%$ あり，文献報告に 比へ比較的少なかった。観察期間を最低 1 年と短 く設定したことによる総症例数の増加も影響して いると思われる。

一側性 MD 症例にゲンタマイシン療法を行う にあたり，将来の対側発症のリスクを予見できる がどうかが今回の検討の目的である。すず疫学的 にみると今回対側発症例は一側性に比べ女性に多 く, 初診時年粭が高く, 発症から初診むでの罹病 期間が長い傾向にあった。初診時年齢から初診交 での籗病期間を引いた值が発症時年齢となるが,

こちらも一側例が約46歳であるのに対し両側例で は約59歳で両側例が高かった。初発から対側発症 までの罹病期間については多くの報告で 2 年以内 に約半数が発症するとされているが，5年以上を 経て対側発症する症例も決して少なくはない。

Paparella and Griebie ${ }^{7)}$ の360人の患者についての 報告では 2 年以内 $51.6 \% ， 3 \sim 5$ 年 $21 \% ， 5$ 年以 上27.4\%であったとされるが，今回の結果は平均 8.7年とさらに長い傾向にあり，10年を超克る症 例が過半数であった。Greven and Oosterveld ${ }^{8)}$ は 両側例の初発から対側発症までの期間は男性4.5 年に対し女性 8.4 年と女性の方が長いと報告して おり，今回も対側発症例に女性の割合が多かった ことが影響しているのかもしれない。両側例の男 女比は今回記載のあった文献ではいずれも女性に

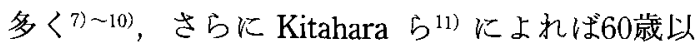
上の発症例の割合は一側性中 $4.9 \%$ に対し両側性 では14.1\%と高值であるとい5。これらも参考に すると，高齢発症の女性において対側発症のリス クが増加する可能性があり, 長期の経過観察が必 要なのではないかと考えられた。

発症から初診までの罪病期間が長いことについ ては，治療歴がある症例も混在していると考克ら れるが，治療の詳細は不明である。早期の適切な 治療があるいは対側発症の予防となるのではない かといら可能性も考兄られる。

内耳機能検查の結果については，まず聴力型か
ら対側発症例の特徵は得られなかった。初発耳の 聴力型に低音障害が少ないのは，初診時既に罹病 期間が長い症例が多く，病態が進行していたため と考兄られる。これに対し後発耳は低音障害の割 合が比較的多く，初期病態を示している。

対側発症時にめまいを伴わない症例は両耳の病 態が異なる可能性も否定できず，一側性 MDに 対側の聴力変動を合併した症例として報告してい る文献もある10)。ただし今回の対側発症例では対 側にも低音障害が認められ，単純な進行性感音難 聴ではなく聴力変動を認める点からも病態は同様 であり，初期病変のためめまいを伴わない場合が あるのではないかと考察した。対側発症後にグリ セロールテストで内リンパ水腫を確認するのも一 つの手段と考它られる。

カロりックテスト・VEMPの結果と対側発症 については一定の傾向は認められず，これらの検 查結果から初訅時に対側発症を予測することは困 難と考光られた。どちらも基本的に左右の相対值 を比較する検査であり，絶対值を評価するのは難 しい。ただ利尿剤を負荷することによる反応の 変化については，グリセロールテストが聴力正常 耳に行えないのに対し一考の余地がある。グリセ ロール負荷 VEMP の絶対值の変化は聴力正常耳 の内リンパ水腫の誩断に有効との報告があり ${ }^{13)}$, 未来の発症予測は困難と乙ても，治療の時点に括 ける健側の内リンパ水腫の除外診断有益である 可能性が示唆される。

ゲンタマイシン㞠法は施設により様々な投与 量・投与方法が採用されて打り ${ }^{1) 51}$ ，大別して一 定量を数日かけて投与する方法（Shotgun 法）と 患者の反応をみながら少量ずつ期間を叔いて投与 する方法（Titration 法）があるが，めまいのコ ントロール率はいずれも良好である。ちなみに東 京大学耳鼻咽喉科では前者の方法を採用して打 り，ゲンタマイシン 1 アンプル $40 \mathrm{mg}$ を重曹水 で $30 \mathrm{mg} / \mathrm{ml}$ に希釈して 1 日 1 回連続 5 日間鼓膜 切開創より鼓室内に注入している。この処置によ り長期的には大半で温度眼振は消失する。これに 対し機能廃絶をきたさない程度の濃度・回数によ り機能低下にとどめることを目的とした場合，両 側性 MD も必ずしも禁忌とはいえないとしてい る文献もある(14) 16)。両側例14例を治療後 2 年経 過観察した Pyykko ら ${ }^{15)}$ の報告では 4 例に持続的 
な歩行困難が残存したが，他は重心動摇の悪化が 徐々に改善したという。ただし両側例への適用は 至適投与量の決定が困難であり，めまいの責任耳 が決定しにくいといら問題がある。

副作用としての難聴については病状の自然経過 との区別が困難ではあるが，注入後明らかに難聴 が進行した症例が20〜 40\%に認められたと報告さ れている1) 5)。襲になる確率も数\%とされている。 本療法の適応・禁忌についてはやはり各施設の判 断に委小られているといらのが現状のよらであ る。

\section{結 論}

今回の結果では，一側性 MD の対側発症を検 查值で予見することは困難であったが，疫学的傾 向以認められた。これらからゲンタマイシン療法 の注意点をむとめると『一側発症後10年を経過し ても両側移行が起きる可能性は充分あることを念 頭に扔か水ばならず，かつ高龄発症した女性には 特に注意が必要』となる。ただし保存的治療でめ まい発作のコントロールが不可能な症例が対象と いら点を考光ると，両側移行のリスクを恐れて破 壊的治療を先延ばしにするのは現実的ではない。 治療の有益性が両側移行のリスクを上回ると判断 された場合には，データに基づくインフォームド コンセントを得た上でかつ high risk と考えられ る場合は投与量を調節するのが実際的であろらと 考えられた。

本論文の要旨は第62回めまい平衡医学会にて発 表した。

文献

1) Murofushi T, Halmagyi GM, Yavor RA: Intratympanic gentamicin in Meniere's disease: results of therapy. Am J Otol 18: 52-57, 1997

2 ) Kaasinen S, Pyykko I, Ishizaki H, et al: Intratympanic gentamicin in Meniere's disease. Acta Otolaryngol 118: 294-298, 1998

3 ) Youssef TF, Poe DS: Intratympanic gentamicin injection for the treatment of Meniere's disease. Am J Otol 19: 435-442, 1998

4) Atlas JT, Parnes LS: Intratympanic gentamicin titration therapy for intractable Meniere's disease. Am J Otol 20: 357-363, 1999

5 ) Kaplan DM, Nedzelski JM, Chen JM, et al: Intratympanic gentamicin for the treatment of unilateral Meniere's disease. Laryngoscope 110: 1298-1305, 2000

6）渡辺 勈：厚生省研究班メニエール病基準に ついて. 耳鼻臨床 69: 301-303, 1976

7) Paparella MM, Griebie MS: Bilaterality of Meniere's disease. Acta Otolaryngol 97: 233-237, 1984

8) Greven AJ, Oosterveld WJ: The contralateral ear in Meniere's disease. Arch Otolaryngol 101: 608-612, 1975

9 ) Rosenberg S, Silverstein H, Flanzer J, et al: Bilateral Meniere's disease in surgical versus nonsurgical patients. Am J Otol 12: 336-340, 1991

10) Kitahara M: Bilateral aspects of Meniere's disease. Meniere's disease with bilateral fluctuant hearing loss. Acta Otolaryngol Suppl 485: 74-77, 1991

11) Kitahara M, Matsubara $H$, Takeda $T$, et al: Bilateral Meniere's disease. Adv Otorhinolaryngol 25: 117-121, 1979

12) Stahle J, Friberg U, Svedberg A: Long-term progression of Meniere's disease. Acta Otolaryngol 485: 78-83, 1991

13) Murofushi T, Matsuzaki M, Takegoshi H: Glycerol affects vestibular evoked myogenic potentials in Meniere's disease. Auris Nasus Larynx 28: 205-208, 2001

14) Kaplan DM, Nedzelski JM, Chen JM, et al: Intratympanic gentamicin for the treatment of unilateral Meniere's disease. Laryngoscope 110: 1298-1305, 2000

15) Pyykko I, Ishizaki $H$, Kaasinen $S$, et al: Intratympanic gentamicin in bilateral Meniere's disease. Otolaryngol Head Neck Surg 110: 162 $-167,1994$

16) Mcfeely WJ Jr, Singleton GT, Rodriguez FJ, et $\mathrm{al}$ Intratympanic gentamicin treatment for Meniere's disease. Otolaryngol Head Neck Surg 118: 589-596, 1998

原稿到着: 平成16年 4 月23日

別刷請求先 : 松崎真樹

干140-8522 東京都品川区東大井6-3-22

東芝中央病院耳鼻咽喉科 